\title{
Democracy and Continuing Marginalization of Women in Indonesian Politics
}

\author{
Abubakar Eby Hara ${ }^{1, *}$, Agus Trihartono ${ }^{2}$ and Nino Viartasiwi ${ }^{3}$ \\ ${ }^{1}$ Lecturer, Faculty of Social and Political Sciences University of Jember and Researcher, Center for Research in Social \\ Sciences and Humanities (C-RiSSH), University of Jember \\ ${ }^{2}$ Researcher, Center for Research in Social Sciences and Humanities (C-RiSSH), University of Jember \\ ${ }^{3}$ Researcher, Institute of International Relations and Area Setudies, Ritsumeikan University, Kyoto, Japan
}

\begin{abstract}
Although much progress and efforts have been made to increase women's participation in politics, the main idea of women's involvement in politics has not yet penetrated into the mainstream of Indonesian politics. The main idea is not only a representation of the number of female population but also the representation that will bring new norms for Indonesian politics that has been so far dominated by the assumption of masculinity based on power politics and struggle to control resources by one party for the loss of others. This paper seeks to see how this marginalization of women continues to occur. One of the reasons for this cannot be separated from the waning of the reform spirit that inspired the reformation. Slowly but surely Indonesian politics is re-defined in term of power struggles by all means including by corruption, collusion, and nepotism that was once the object of criticism of reform groups. In this context, it is often the case that if women want to succeed in politics, they must follow such political norms and abandons the idealism of their struggle. In fact, such women politicians not only abandon the ideal of feminist struggle but reinforce the assumption that politics is the world of men.
\end{abstract}

Keywords:Democracy, Women Participation, Quota in Parliament, Gender Inequality

\section{Introduction}

Indonesia has held four successful, democratic and fair elections after the fall of Suharto's authoritarian regime in 1998. Theoretically, in this democratic system, all citizens with sufficient conditions without regard to gender, ethnicity, and religion have equal opportunity to vote and be elected. However, in practice, this is not always so. There are always special groups and marginalized groups. One example is in relation to women's groups. Men still enjoy privileges in politics because they are perceived as capable of formulating how politics should work. Politics is seen as a male world because it contains struggle for power to control others, which does not fit to women. This assumption is perhaps formulated with specific reference to Machiavelli's views of 'end justifies the means'. Although Machiavelli also said about Fortuna in his book The Prince which represents the virtues of goodness and wisdom, the Fortuna has become unimportant in male's dominated definition of what politics should be[1].

This paper assumes that politics depends on how actors define and shape it. Although the Indonesian system has been viewed as democratic by many observers[2], the process of strengthening democratic values depends on its perpetrators. We further wish to discuss politics within the framework of the contest of idea to define politics. In particular, we will elaborate how the views of women commonly carried by feminist groups have not been part of a hegemonic political discourse.

Women have a diverse role starting from basic role to taking care of their families until their responsibilities to teach their children take care of nature and environment. Environment really important to woman because they interact more with the environment and natural resources. The impact of environmental damage is more often felt by women. Beside that woman has another role to take care of themselves by following their dream until joining political world.

\section{Methodology}

This paper uses feminist approach. Feminism ideas and views on gender equality strengthened and got new spirit during the reform period. Awareness of equal rights between men and women and the need to end discrimination in employment began to gain a place in public space[3]. Women also state that their experiences in life and what they imagine about politics differ from men's experiences. In particular, bad and inhumane experiences make them know better than men about what politics should be[4]. This justifies the claim that women should obtain a corresponding representation of the female population in both parliament and government.

In feminist perspective, by having more representatives in parliament and government, women can engage further in policy-making processes that can 
lead to laws to reduce the likelihood of violence against women and pay more attention to the welfare of women and children. To know whether gender matter in politics we use bivariate analysis to available data from a survey[5]. Although in Indonesian politics, there is a tendency for identity politics to decrease, the public opinion survey through the exit polls as seen in table 1 shows that gender persists. For the exit polls, typical characteristics have a margin of sampling error of plus or minus $1 \%$. Furthermore, randomly selected voters of the total respondents 1,894 people from 1,894 polling stations across the country were face-to-face interviewed by trained interviewers on April 9, 2015.

Table 1. Bivariate Analyses: Difference in Predicted Probabilities

\begin{tabular}{|c|c|c|}
\hline & $\begin{array}{c}\text { Candidat } \\
\text { e Team2 }\end{array}$ & $\begin{array}{c}\text { Candidat } \\
\text { e Team1 }\end{array}$ \\
\hline Gender & $-0.06^{*}$ & $0.06^{*}$ \\
\hline Rural & $-0.06^{*}$ & $0.06^{*}$ \\
\hline Age & 0.06 & -0.06 \\
\hline Education & $-0.15^{* * *}$ & $0.15^{* * *}$ \\
\hline Ethnicity & $0.10^{* * *}$ & $-0.10^{* * *}$ \\
\hline Religion & $-0.31^{* * *}$ & $0.31^{* * *}$ \\
\hline $\begin{array}{c}\text { Moslem } \\
\text { Religiosity }\end{array}$ & -0.08 & 0.08 \\
\hline \multicolumn{2}{|c|}{$* * p<0.001,{ }^{* *} p<0.01,{ }^{*} p<0.05$} \\
\hline
\end{tabular}

\section{Discussion}

The finding shows that sociological variables such as religion, ethnicity, region, gender, education, and income resembled meaningful in the election. After each sociological variable was controlled by other sociological variables and sociological variable was controlled by non-sociological variables (political economy, quality of candidates, campaign issues, presidential debates, and the political party background) the effect of sociological variables towards the decision of the voters seems insignificant. In other words, based on regression analysis of each sociological variables controlled by other non-sociological variables, the effect of variable which forms identity politics on voter's choice is not convincing. This exit polls revisited the assumptions remained of the supremacy of identity politics in the 2014 presidential contest[6]. It is safe to say that identity politics seems merely a political commodity echoed in the campaign rather than a voters' attitude mirrored in the ballots. The finding suggests that political identity (statistically) did not significantly reflect in voter's behavior of the 2014 Presidential Election. Rather, the only sociological variable seems still quite significant is gender.

Although there is progress in number as in table 2 , the above survey results indicate that gender matters and politics is still defined in the eyes of men. Politics is an arena for power struggles that are not appropriate for women. Politics is a struggle to defeat each other and in that perspective, what are especially necessary are the financial and other resources as much as possible. Another survey confirmed this situation[7]. According to this survey, when respondents were given choices between a man and a women candidate, $55 \%$ of them will choose man and only $11 \%$ will choose women candidates. Around $32 \%$ of them answered that there were no differences between man and women candidates and $2 \%$ said they did not know.

To win and survive in politics, a persistent view in society is that people must have a lot of money, strong sources and political networks. Most women are then reluctant to get involved in politics because they feel they will dirty their hands with every effort to find these sources and get caught up in an endless political battle. Such politics continued the New Order-led politics that were carried out with the logic of money politics and political thuggery[8].

There has been actually the increase of women's votes in parliament from just 9 percent during the New Order to 12 percent in parliament and now ranges between 17 and 18 percent both in the 2009 and 2014 elections.

Despite some progress above, democracy in Indonesia often produces laws and regulations that are not pro-women. In the case of women, even the system often reinforces the patriarchal system in society[10]. For example, shariah regulations made in some districts depart from assumptions about the position of women who are not equal and lower than men. This can be seen from the regulation that mentions women should be arranged to perform certain behaviors because otherwise, he would be unsafe from male disorders[11]. The Law, in other words, blames women, instead of protecting women. The Laws are not created to punish those who provide insecurity to or threaten women.

The view that politics is the world of men is in some cases reinforced by women politicians themselves which entangled corruption cases. Some regional heads such as in Banten, Cimahi, Banyuwangi, Klaten, Tegal, Minahasa Utara, and Kutai Kartanegara occupied by women, for example, were caught by Indonesia AntiCorruption Commission (KPK) for corruption. This reinforces the assumption that when people speak politics, both women and men are the same. To some extent, this system of democracy has perpetuated a patriarchal system in which men define politics. Many policies have been informed by masculinity-dominant discourses. The discourses create, reinforce, and maintain gendered conditions of politics.

There is certainly case that women's leadership gives different nuances and is sensitive to the interests of women. Surabaya Mayor Tri Rismaharini is one example of woman leaders who has sensitivity to the experience and suffering of women. She, for example, closed down Dolly, the biggest prostitution complex in Southeast Asia and managed to set the city neatly decorated with city gardens and flowers. This phenomenon is not much but gives a sense that if women seriously materialize their missions in in politics, then they will be able to bring their experience and sensitivity in the programs taken. 
According to Milner, politics is the process of invention[12]. Politics depends on how actors define what politics should be. Through textual analysis of the colonial Malaysia, Milner pointed out how the Malay questioned the role of King and expanded the public sphere by bringing ideas of nationalism and democracy that shaped Malaysian politics in the future. In the same paradigm, Ben Anderson discussed how Indonesians spoke about the nation of Indonesia since before the independence[13]. Also through text analysis, he argued that Indonesia started with a kind of imagined community which was then shared jointly by the community through the print media during the colonial time.

From these two views, politics, in other words, can be defined and shaped by its actors. What kind of politics should be is the result of the ideas of the actors themselves. The actors then expand the ideas through media and dialogs in society. It may then be followed by an inter-subjective understanding among the majority of people regarding what needs to be done. This has been happened in 1998 when Indonesians shared the ideas of reform and of the necessity to replace Suharto in 1998. At the time of the overthrow of Suharto, the key words used were reformasi and the fight against the acute Collusion, Corruption, and Nepotism. By using similar perspective, women need to continue their struggle by bringing their norms to redefine politics which can be friendlier and conducive to women, children, family and therefore all citizens' welfare.

\section{Conclusion}

The general phenomenon about women's struggle in politics shows that women's agenda in politics, is just entering the initial stage and needs to be fought further. Feminists and gender equality advocates generally believe that women's representation will inform the importance of a more cooperative, peaceful and focused policy on the welfare of family, women, and children. But this is hampered by the growing political discourse that defines politics as the male world, that politics is a job that justifies all means for the sake of power. Such views are becoming increasingly hegemonic in society. This has the consequence that women end up having to sacrifice idealism and plunge into the male hegemonic politics. Feminist and female activists need to continue to revive their initial vision of women's struggles to define or color the political discourse.

\section{References}

1. A. E. Hara, "A Gendered Battle: Human Security and Women's Struggle for Equality in Indonesia's New Democratic Era”, in Brennen Jenkins (ed.), Mainstreaming Human Security: The Asian
Contribution" , Chulalongkorn University, Bangkok (2012).

2. A. E. Hara, "Pancasila and Perda sharî'ah Debates in the Post-Soeharto Era: toward a New Political Consensus", M. Okamoto, A. Ota, and S. Ahmad (eds.), Chapter 3 in, "Islam in Contention: Rethinking Islam and State in Indonesia", Center for Southeast Asian Studies, Kyoto (2010).

3. A. Milner, "The Invention of Politics in Colonial Malaya", Cambridge University Press, Cambridge (2002).

4. A. Trihartono, and H.B. Patriadi, "The 2014 Indonesian general election and beyond Melting "frozen" cleavages', Asian Journal of Comparative Politics", Vol. 1, No. 1, pp. 25-43 (2016).

5. A. Trihartono, "Beyond Measuring the Voice of the People: The Evolving Role of Political Polling in Indonesia's Local Leader Elections, Southeast Asian Studies", Vol. 3, No. 1, pp.151-182, April (2014).

6. B. Anderson, "Imagined Communities: Reflections on the Origin and Spread of Nationalism", Verso, London (1991).

7. Ihsanuddin, "Survei: Perempuan Masih Dipandang Sebelah Mata di Dunia Politik Indonesia", kompas.com 11 February (2014).

8. S. McKay, "Women, Human Security, and Peacebuilding: A Feminist Analysis", Conflict and Human Security: A Search for New Approaches of Peace-building, Chapter 7, IPSHU English Research Report Series No.19, p. 154 (2004).

9. N. Machiavelli, "The Prince", University of Chicago Press, Chicago (1985).

10. S. Mujani, "Research and Consulting (SMRC), Exit polls of the 2014 general election, Indonesia", April (2014).

11. U. Kristoffersson, "HIV/AIDS as a Human Security Issue: A Gender Perspective, Expert Group Meeting on the HIV/AIDS Pandemic and its Gender Implications" , 13-17 November, Windhoek, Namibia (2000).

12. V. R. Hadiz, "Reorganizing political power in Indonesia: a reconsideration of so-called 'democratic transitions"', The Pacific Review, Vol. 16, No. 4, p. 594, (2003).

13. Republika, www.republika.co.id, "Ini Dia Profil Anggota Legislatif 2014-2019” accessed 10 October 2017, (2014).

14. Kompas Perempuan, www.komnasperempuan.go.id, "Kertas Posisi RUU Pemilu", accessed on 10 October 2017 (2013). 